Kunuz: Journal of Islamic Banking and Finance Vol. 1, No. 1 (2021): 53-60 Website: http://ejournal.iain-manado.ac.id/index.php/kunuz

\title{
PENGARUH PRICE EARNING RATIO TERHADAP HARGA SAHAM PERUSAHAAN YANG TERDAFTAR DI JAKARTA ISLAMIC INDEX (JII)
}

\author{
Nurul Azizah Azzochrah \\ Fakultas Ekonomi dan Bisnis Islam, Institut Agama Islam Negeri Manado Indonesia \\ E-mail: nurul.azzochrah@iain-manado.ac.id
}

Muhammad Azhar Mushlihin

Fakultas Ekonomi dan Bisnis Islam, Institut Agama Islam Negeri Manado Indonesia E-mail: azhar.m@iain-manado.ac.id

\author{
Misbahul Munir Makka \\ Fakultas Syariah, Institut Agama Islam Negeri Manado Indonesia \\ E-mail: misbahulmakka66@gmail.com
}

\begin{abstract}
ABSTRAK
Nilai saham perusahaan dapat dipengaruhi oleh beberapa faktor diantaranya return on equity, ukuran perusahaan, dan price earning ratio. Penelitian ini bertujuan untuk membuktikan secara empiris pengaruh Price Earning Ratio terhadap harga saham yang terdaftar pada Jakarta Islamic Index (JII). Metode penelitian yang digunakan dalam penelitian ini adalah penelitian kuantitatif dengan melakukan pengumpulan populasi antara lain beberapa perusahaan yang terdaftar di Jakarta Islamic Index dengan sampel 8 perusahaan yang tidak pernah delisting selama priode 2018-2021 di Jakarta Islamic Index. Analisis data menggunakan analisis regresi linear sederhana yang digunakan untuk mengetahui hubungan antara variabel dependen dengan variabel independen dengan menggunakan aplikasi SPSS. Selain analisis regresi sederhana, uji normalitas juga dilakukan untuk mengetahui apakah data yang akan diolah nantinya benar atau dapat terdistribusi secara baik. Hasil penelitian ini menunjukan bahwa Price Earning Ratio memiliki pengaruh positif terhadap harga saham di Jakarta Islamic Index. Investasi dilakukan khusus pada saham-saham yang berada pada Jakarta Islamic Index (JII) ternyata mendapatkan nilai positif yang menandakan bahwa ketika nilai Price Earning Ratio (PER) itu mengalami kenaikan.
\end{abstract}

Kata kunci: Harga saham, Jakarta Islamic Index, Price Earning Ratio (PER)

Pengaruh Price Earning Ratio Terhadap Harga Saham Perusahaan yang Terdaftar di Jakarta Islamic Index (JII)

Nurul Azizah Azzochrah, Muhammad Azhar Mushlihin, Misbahul Munir Makka 


\section{PENDAHULUAN}

Pasar modal di setiap negara mempunyai peran penting untuk menggerakkan perekonomian khususnya dalam bidang keuangan. (Jamil \& Hayati, 2021; Permata \& Ghoni, 2019) Dalam menjalankan fungsi, pasar modal menyediakan tempat untuk memindahkan dana dari pihak yang mempunyai kelebihan dana ke pihak yang membutuhkan dana. Pasar modal telah tumbuh menjadi bagian yang penting dari perekonomian Indonesia sebagai alternatif pendanaan bagi perusahaan-perusahaan selain perbankan. Pasar modal sebagai sumber pendanaan suatu perusahaan yang berimplikasi bagi perekonomian negara bukan hanya sekedar alternatif tetapi sudah mampu menjadi pendanaan utama (Badriatin et al., 2019; Jamil \& Hayati, 2021; Permata \& Ghoni, 2019).

Perusahaan yang membutuhkan tambahan modal untuk menjalankan kegiatan perusahaannya dapat memanfaatkan pasar modal. Dalam hal ini perusahaan dapat memperoleh tambahan modal dengan cara menjual sahamnya di pasar modal yang nantinya akan dibeli oleh masyarakat atau pihak yang mempunyai kelebihan dana. Ini merupakan cara memperoleh dana yang paling murah, cepat dan mudah. Saham merupakan instrumen yang paling banyak dipilih oleh investor dalam melakukan investasi di pasar modal, dimana saham merupakan suatu tanda kepemilikan akan suatu perusahaan (Fakhruddin, 2008)

Bursa efek adalah sebuah pasar yang akan menghubungkan antara penjual dan pembeli efek perusahaan yang sudah terdaftar di bursa tersebut. Surat berharga yang diperjual belikan di Bursa Efek adalah saham dan obligasi. Bursa efek memiliki beberapa jenis perusahaan/ bidang usaha. Salah satu kategori dalam bursa efek yang cukup banyak menarik perhatian masyarakat pada saat ini adalah Jakarta Islamic Index atau yang biasa di sebut JII (Hadinata, 2018; Siddiq \& Suseno, 2019).

Jakarta Islamic Indeks pertama kali muncul pada tahun 2000 yang terdiri dari 30 saham perusahaan yang masuk dalam kategori Syariah yang paling likuid. Perkembangan saham syariah yang dinilai cukup signifikan membuat para investor mulai melirik saham-saham yang berbasis Syariah, hal ini bukan hanya disebabkan karena adanya syarat syariahnya namun saham Syariah dinyatakan memiliki ketahanan terhadap krisis ekonomi (Amalia \& Kartikasari, 2016).

Analisis terhadap saham perusahaan adalah langka penting yang harus dilakukan oleh para investor sebelum membeli sebuah saham perusahaan. Terdapat beberapa analisis yang dapat digunakan untuk menilai kelayakan suatu saham perusahaan yaitu, analisis fundamental dan analisis teknikal (Agustina, 2021).

Analisis fundamental adalah menganalisa hal-hal yang berkaitan dengan keuangan perusahaan, yang mana nilai saham dipengaruhi oleh kinerja perusahaan. Sedangkan analisis teknikal adalah pelengkap dari analisis fundamental yang menganalisa data harga saham di masa lalu sebagai upaya untuk memperkirakan harga saham di masa mendatang (Aletheari \& Jati, 2016). Menurut Tryfino (2009:18) dalam (Sari, 2018) dasar untuk menganalisis harga saham yakni dengan analisis fundamental 
Kunuz: Journal of Islamic Banking and Finance Vol. 1, No. 1 (2021): 53-60 Website: http://ejournal.iain-manado.ac.id/index.php/kunuz

dan analisis laporan keuangan berupa analisis rasio termasuk dalam komponen yang digunakan pada analisis fundamental.

Mengetahui fundamental suatu saham akan sangat membantu investor untuk menghindari membeli saham yang berkinerja buruk (Rahmat, 2018). Yang dimaksud saham berkinerja buruk adalah saham suatu perusahaan yang tidak dapat menghasilkan laba atau rugi terus-menerus. Kondisi seperti ini tentu akan berpengaruh terhadap pergerakan harga sahamnya.

Analisis fundamental juga dipakai untuk menganalisis tingkat kewajaran harga suatu saham. Mengukur tingkat kewajaran suatu saham biasanya adalah dengan membandingkan rasio-rasio keuangan tertentu dengan saham lainnya yang bergerak dalam bisnis yang sama.

Salah satu metode yang dapat dilakukan oleh investor untuk menilai kelayakan dari suatu saham yaitu dengan menggunakan Price Earning Ratio (PER) yang dimiliki oleh perusahaan tersebut (Kusumadewi \& Sudiartha, 2016). Price Earning Ratio (PER) merupakan variabel keuangan yang dapat dijadikan sebagai komponen utama dalam analisis fundamental perusahaan.

Price Earning Ratio digunakan untuk menentukan apakah investasi yang dilakukan menguntungkan atau merugikan, dengan cara membandingkan antara harga per lembar saham dengan laba bersih per sahamnya (Susanti, 2018). Price Earning Ratio (PER) ini melihat seberapa besar kemampuan yang dimiliki oleh suatu perusahaan dalam menghasilkan laba dimana rasio ini menggambarkan kemampuan dari atau kesediaan para investor membayarkan suatu jumlah tertentu untuk setiap rupiah perolehan laba perusahaan tersebut (Desiana, 2017).

Pada penelitian ini, penulis tertarik untuk melakukan penelitian dan mengambil sampel perusahaan yang terdaftar dalam Jakarta Islamic Index (JII). Tujuan dari penelitian ini adalah untuk mengetahui dan menganalisis pengaruh Price Earning Ratio terhadap harga saham yang terdaftar pada Jakarta Islamic Index. Hasil penelitian ini diharapkan dapat memberikan manfaat bagi berbagai pihak, sebagai bahan pertimbangan dalam menetapkan pilihan investasi untuk membuat berbagai kebijakan sehingga dapat mengoptimalkan keuntungan dan meminimalkan resiko atas investasi dananya, serta dapat menambah pengetahuan pihak-pihak terkait.

\section{METODE PENELITIAN}

Penelitian ini merupakan penelitian Kuantitatif. Pada penelitian peneliti mengambil objek penelitian yakni perusahaan yang terdaftar di Jakarta Islamic Index (JII) dari tahun 2018-2021, terdapat 30 peruhaan yang terdaftar pada Jakarta Islamic Index. Sampel dalam penelitian ini adalah 8 perusahaan yang tidak pernah delisting selama 2018-2021 di Jakarta Islamic Index. 
Kunuz: Journal of Islamic Banking and Finance Vol. 1, No. 1 (2021): 53-60 Website: http://ejournal.iain-manado.ac.id/index.php/kunuz

Tabel 1.

Daftar Perusahan di Jakarta Islamic Index

\begin{tabular}{|c|c|c|c|}
\hline NO & KODE & NAMA PERUSAHAAN & INDUSTRI \\
\hline 1 & ANTM & Aneka Tambang (Persero) Tbk & Mining \\
\hline 2 & ASII & Astra International Tbk. & Misc Industry \\
\hline 3 & CPIN & $\begin{array}{l}\text { Charoen Pokphand Indonesia } \\
\text { Tbk }\end{array}$ & Chemical Industry \\
\hline 4 & EXCL & XL Axiata Tbk & Infrastructure \& Transportation \\
\hline 5 & INDF & Indofood Sukses Makmur Tbk & Consumer Goods \\
\hline 6 & TLKM & $\begin{array}{l}\text { Telkomunikasi } \quad \text { Indonesia } \\
\text { (Persero) Tbk. }\end{array}$ & Infrastructure \& Transportation \\
\hline 7 & UNTR & United Tractors Tbk & Trade, Service \& Investment \\
\hline 8 & UNVR & Uniliver Indonesia Tbk. & Consumer Goods \\
\hline
\end{tabular}

Sumber: Jakarta Islamic Index (www.idx.co.id)

Pengambilan data dilakukan dengan mengambil data laporan keuangan dari situs Bursa Efek Indonesia (www.idx.co.id) dengan metode dokumentasi. Data kuantitatif yang digunakan dalam penelitian ini adalah laporan keuangan setiap perusahaan yang terdaftar di Jakarta Islamic Index. Analisis data menggunakan analisis regresi linear sederhana yang digunakan untuk mengetahui hubungan antara variabel dependen dengan variabel independen dengan menggunakan aplikasi SPSS. Selain dari analisis regresi sederhana, penulis juga melakukan uji normalitas dimana untuk mengetahui apakah data yang akan diolah nantinya benar atau dapat terdistribusi secara baik.

\section{HASIL DAN PEMBAHASAN}

\section{Uji Normalitas}

Uji normalitas bertujuan untuk menguji apakah dalam suatu model regresi linier variabel terikat dan variabel bebas keduanya mempunyai distribusi normal atau tidak. Model regresi yang baik adalah yang memiliki distribusi data normal atau mendekati normal (Ghozali, 2006).

Alat analisis yang digunakan dalam uji ini adalah menggunakan histogram dan plot normal. Dasar pengambilan keputusan normal atau tidaknya data yang diolah adalah jika sebaran data menyebar merata ke semua daerah kurva normal, sehingga dapat disimpulkan bahwa data mempunyai distribusi normal. Demikian juga dengan output normal plot bahwa sebaran data mendekati garis normal atau di sekitar garis diagonal dan mengikuti arah garis diagonal, sehingga dapat disimpulkan bahwa data mempunyai distribusi normal. 


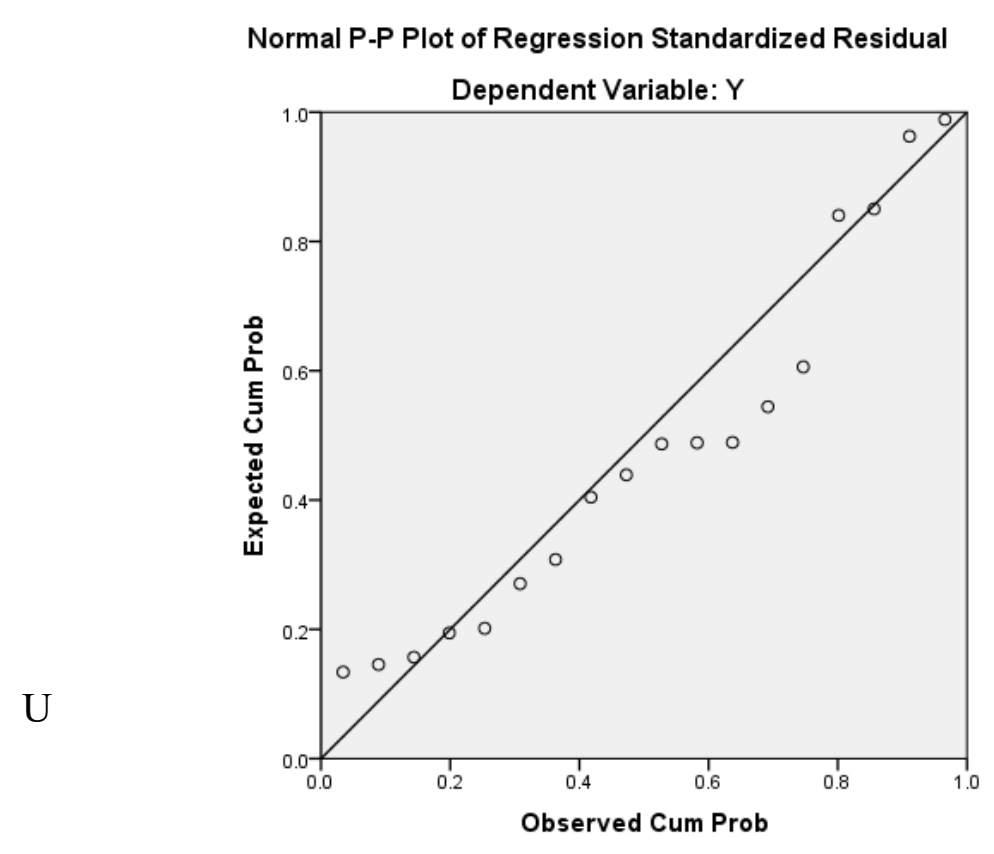

Gambar 1. Grafik uji normalitas residual

Uji normalitas ini dilakukan menggunakan bantuan SPSS 24 terlihat dari grafik di atas penyebaran data (titik) pada sumbu diagonal mengikuti arah garis diagonal sehingga dapat disimpulkan bahwa model regresi memenuhi asumsi normalitas.

\section{Tabel 2.}

\section{Analisis Regresi Sederhana}

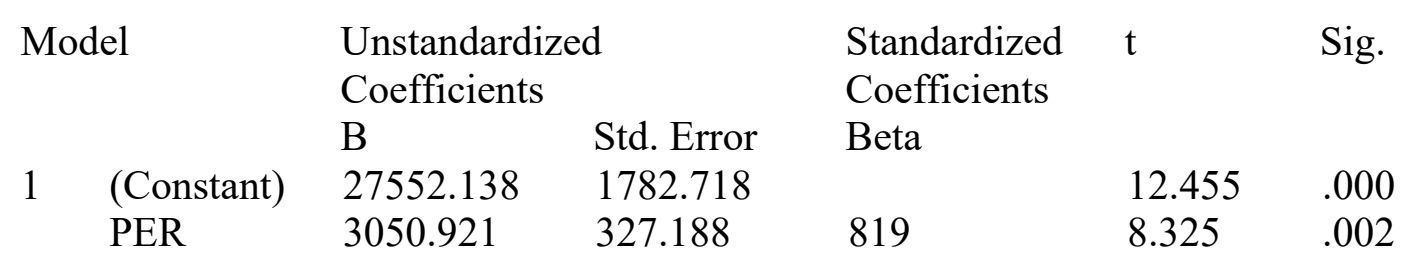

Koefisien model regresi memiliki nilai constant sebesar 27552.138 dengan nilai t hitung 8.325 dan nilai sig. sebesar 0,02 .

Price Earning Ratio (PER) mempunyai t hitung sebesar 8.325 dengan probabilitas signifikansi adalah 0,02 dan nilai beta yang dihasilkan adalah positif sebesar 819 . Hal tersebut menunjukkan bahwa probabilitas signifikansinya di bawah 0,05 .

\section{PEMBAHASAN}

Hasil penelitian ini membuktikan bahwa bagi para investor, Price Earning Ratio (PER) dapat dijadikan sebagai salah satu indikator oleh investor dalam 
berinvestasi di Bursa Efek Indonesia. Investasi dilakukan khusus pada saham-saham yang berada pada Jakarta Islamic Index (JII). Hasil pengujian regresi didapatkan nilai positif yang menandakan bahwa ketika nilai Price Earning Ratio (PER) itu mengalami kenaikan maka hal yang sama juga ditunjukkan oleh harga saham yang dimiliki oleh perusahaan tersebut.

Nilai dari Price Earning Ratio adalah rasio yang digunakan untuk melihat hubungan antara harga saham di pasaran (dalam hal ini harga saham penutupan yang diambil) dengan nilai Earning per Share saat ini yang digunakan secara luas oleh investor sebagai acuan umum untuk dapat mengukur seberapa besar nilai saham tersebut.

Price Earning Ratio (PER) itu sendiri merupakan salah satu variabel yang menjadi pertimbangan seorang investor dalam mengambil keputusan dalam melakukan investasi, apakah akan menahan saham-saham yang mereka miliki ataukah akan menjual saham yang telah mereka investasikan.

Terdapat beberapa kriteria investor di dalam Bursa Efek, (Tumbel et al., 2017) dimana yang pertama adalah investor yang mengandalkan keuntungan dari Capital Gain yaitu selisih antara nilai beli dan nilai beli saham. Yang kedua Investor yang mengandalkan deviden dari saham-saham yang mereka milikiinvestor yang memiliki sifat seperti ini relative menahan investasi yang mereka miliki ketika melihat nilai Price Earning Ratio (PER) bahwa nilai dalam hal ini adalah saham yang mereka miliki hal ini disebabkan karena mereka menilai bahwa perusahaan dapat menggelola dana yang mereka investasikan di perusahaan tersebut dapat dikelola dengan baik. Terakhir adalah investor yang mengandalkan keduanya dimana investor ini memanfaatkan keuantungan dari deviden dan juga Capital Gain dari perusahaanperusahaan yang mereka letakkan investasinya.

\section{Pengaruh Price Earning Rasio Terhadap Harga Saham}

Pengaruh Price Earning Ratio (PER) merupakan rasio pasar yang digunakan dalam melihat bagaimana pasar mengukur kinerja saham suatu perusahaan terhadap kinerja saham yang digambarkan oleh Earning per Share (EPS), semakin besar Price Earning Ratio perusahaan maka saham tersebut akan semakin mahal terhadap pendapatan bersih per lembar saham, begitupun sebaliknya semakin kecil Price Earning Ratio perusahaan maka saham tersebut akan semakin murah.

Saham yang memiliki Price Earning Ratio (PER) semakin kecil menandakan bahwa saham tersebut dalam keadaan yang murah sedangkan sebaliknya ketika nilai Price Earning Ratio (PER) yang di tunjukkan itu tinggi maka nilai saham itu sedang meningkat atau sedang banyak diminati oleh para investor. Dalam penelitian ini PER berpengaruh positif terhadap harga saham yang dimana diasumsikan bahwa para investoryang tertarik dalam mebeli saham yang masuk dalam kategori di Jakarta Islamic Index (JII) dapat menjadikan Price Earning Ratio (PER) sebagai rujukan dalam mengambil keputusan untuk melihat bagaimana keadaan dari saham tersebut.

Pengaruh Price Earning Ratio Terhadap Harga Saham Perusahaan yang Terdaftar di Jakarta Islamic Index (JII) 
Dalam hal ini nilai Price Earning Ratio (PER) yang tinggi dapat menunjukan bahwa tingkat laba perlembar saham yg dihasilkan perusahaan adalah tinggi. Yang jika dibandingkan pada harga saham tersebut. Hal ini juga memberikan gambaran bahwa perusahaan-perusahaan yang memiliki Price Earning Ratio yang tinggi maka perusahaan tersebut dapat memaksimalkan keuntungan dari investasi yang investor lakukan pada perusahaannya atau dengan kata lain perusahaan tersebut sedang banyak di minat oleh para investor.

\section{KESIMPULAN}

Terdapat pengaruh yang positif dan juga signifikan antara Price Earning Ratio (PER) terhadap harga saham perusahaan yang ada pada Jakarta Islamic Index (JII). Terlihat bahwa koefisien model regresi memiliki nilai constant sebesar 27552.138 dengan nilai t hitung 8.325 dan nilai sig. sebesar 0,02. Investasi dilakukan khusus pada saham-saham yang berada pada Jakarta Islamic Index (JII) ternyata mendapatkan nilai positif yang menandakan bahwa ketika nilai Price Earning Ratio (PER) itu mengalami kenaikan. Maka hal yang sama juga ditunjukkan oleh harga saham yang dimiliki oleh perusahaan tersebut.

\section{DAFTAR PUSTAKA}

Agustina, R. (2021). Analisis Fundamental, Acuan Investasi Saham Jangka Panjang. DINAMIS: Jurnal Pengabdian Kepada Masyarakat, 1(1), 14-25.

Aletheari, I., \& Jati, I. (2016). Pengaruh Earning Per Share, Price Earning Ratio, Dan Book Value Per Share Pada Harga Saham. E-Jurnal Akuntansi, 17(2), 12541282.

Amalia, A. D., \& Kartikasari, D. (2016). Analisis Perbandingan Kinerja Saham Perusahaan Manufaktur Terindeks Syariah dan Konvensional. Jurnal Akuntansi, Ekonomi Dan Manajemen Bisnis, 4(2), 128-135.

Badriatin, T., Rinandiyana, L. R., Mujtahidin, F. W., \& Mulyani, E. L. (2019). Capital Market Literation Program in Class. Journal of Character Education Society, 2(1), 24-29.

Desiana, L. (2017). Pengaruh price earning ratio (PER), earning per share (EPS), devidend yield ratio (DYR), dividend payout ratio (DPR), book value per share (BVS) dan price book value (PBV) terhadap harga saham pada perusahaan subsektor makanan dan minuman yang terdaftar d. I-Finance: A Research Journal on Islamic Finance, 3(2), 199-212.

Fakhruddin, H. M. (2008). Istilah pasar modal AZ: berisi kumpulan istilah populer pasar modal khususnya di pasar modal Indonesia, mencakup berbagai istilah seputar perdagangan saham, obligasi, reksa dana, instrumen derivatif dan berbagai istilah terkait lainnya. Elex Media Komputindo.

Hadinata, S. (2018). Tingkat Pengembalian (Return), Risiko, dan Koefisien Variasi pada Saham Syariah dan Saham Nonsyariah. AKTSAR: Jurnal Akuntansi Syariah, 1(2), 171-186.

Jamil, P. C., \& Hayati, R. (2021). Pasar Modal dan Penanaman Modal Asing di Indonesia. COSTING: Journal of Economic, Business and Accounting, 4(2), 477484. 
Kusumadewi, D. G. S., \& Sudiartha, G. M. (2016). Pengaruh Likuiditas, Dividend Payout Ratio, Kesempatan Investasi Dan Leverage Terhadap Price Earning Ratio. E-Jurnal Manajemen Unud, 5(9), 156-166.

Permata, C. P., \& Ghoni, M. A. (2019). Peranan Pasar Modal Dalam Perekonomian Negara Indonesia. Jurnal AkunStie (JAS), 5(2), 50-61.

Rahmat, Y. A. (2018). The Influence of Book Value (BV), Price to Book Value (PBV), Earnings Per Share (EPS) and Price Earning Ratio (PER) to Stock Price of Agribussiness Company Year 2012-2017.

Sari, A. P. (2018). Analisis Faktor Fundamental dan Laba Akuntansi terhadap Harga Saham pada Sub Sektor Lembaga Pembiayaan di BEI. J-MAS (Jurnal Manajemen Dan Sains), 3(1), 1. https://doi.org/10.33087/jmas.v3i1.38

Siddiq, F. R., \& Suseno, A. E. (2019). Fraud Pentagon Theory Dalam Financial Statement Fraud Pada Perusahaan Terdaftar di Jakarta Islamic Index (JII) Periode 2014-2017 (Perspektif F-Score Model). Jurnal Nusantara Aplikasi Manajemen Bisnis, 4(2), 128-138.

Susanti, O. (2018). Pengaruh Current Ratio, Debt To Equity Ratio dan Total Asset Turnover Terhadap Price Earning Ratio Pada Perusahaan PT. Suparma, Tbk. EJournal Manajemen" BRANCHMARCK", 4(1).

Tumbel, G. A., Tinangon, J., \& Walandouw, S. K. (2017). Pengaruh Laba Akuntansi dan Arus Kas Operasi Terhadap Return Saham Pada Perusahaan Manufaktur Sektor Industri Barang Konsumsi yang Terdaftar Di Bursa Efek Indonesia. Jurnal EMBA: Jurnal Riset Ekonomi, Manajemen, Bisnis Dan Akuntansi, 5(1). 